OPEN ACCESS

Edited by:

Muhammad Ibrahim Abdullah,

COMSATS University Islamabad,

Lahore Campus, Pakistan

Reviewed by:

Afzal Ahmed Dar,

Shaanxi University of Science and

Technology, China

Muhammad Fahad Sardar,

Chinese Academy of Agricultural

Sciences (CAAS), China

*Correspondence:

Yaoping Liu

yaoping.@@mail.rmutk.ac.th

Haider Ali Malik

gujranwalaanam091@gmail.com

Specialty section:

This article was submitted to

Organizational Psychology,

a section of the journal

Frontiers in Psychology

Received: 07 February 2021

Accepted: 22 March 2021

Published: 14 May 2021

Citation:

Dong D, Malik HA, Liu Y, Elashkar EE,

Shoukry AM and Khader JA (2021)

Battling for Consumer's Positive

Purchase Intention: A Comparative

Study Between Two Psychological

Techniques to Achieve Success and

Sustainability for Digital

Entrepreneurships.

Front. Psychol. 12:665194.

doi: 10.3389/fpsyg.2021.665194

\section{Battling for Consumer's Positive Purchase Intention: A Comparative Study Between Two Psychological Techniques to Achieve Success and Sustainability for Digital Entrepreneurships}

\author{
Dandan Dong ${ }^{1}$, Haider Ali Malik ${ }^{2 *}$, Yaoping Liu ${ }^{3,4 *}$, Elsayed Elsherbini Elashkar ${ }^{5,6}$, \\ Alaa Mohamd Shoukry ${ }^{7,8}$ and J. A. Khader ${ }^{9}$
}

${ }^{1}$ School of Journalism and Communication, Nanjing University, Nanjing, China, ${ }^{2}$ FAST School of Management, National University of Computer and Emerging Sciences, Islamabad, Pakistan, ${ }^{3}$ Department of Business Administration, Rajamangala University of Technology Krungthep, Bangkok, Thailand, ${ }^{4}$ Department of Business Administration, Mahidol University, Salaya, Thailand, ${ }^{5}$ Administrative Sciences Department, Community College, King Saud University, Riyadh, Saudi Arabia, ${ }^{6}$ Applied Statistics Department, Faculty of Commerce, Mansoura University, Mansoura, Egypt, ${ }^{7}$ Arriyadh Community College, King Saud University, Riyadh, Saudi Arabia, ${ }^{8}$ Department of Business Administration, KSA Workers University, Nsar, Egypt, ${ }^{9}$ College of Business Administration, King Saud University Muzahimiyah, Al-Muzahmiyya, Saudi Arabia

This research focuses on students' online purchase intentions in Pakistan toward different products available for sale on numerous e-business websites. This study's main objective is to determine which methodology is better to enhance customer online purchase intention. It also aims to discover how to improve perceived benefits and lower perceived risks associated with any available online product and entrepreneurship. AMOS 24 has been used to deal with the mediation in study design with bootstrap methodology. The study was conducted on 250 students from different educational institutes in Pakistan using a simple random sampling technique. A finding of this study suggests that both methods positively impact online purchase intention of consumers and sustainable digital economy. But social media advertisement is more effective through enhancing the perceived benefits of products. In contrast, product content factors are more effective at lowering the perceived risks associated with available online products.

Keywords: purchase intentions, online purchase intention, perceived risk, social media, e-business, entrepreneurship, organizational sustainability

\section{INTRODUCTION AND BACKGROUND}

In recent decades, social media has been a valuable addition to our everyday lives (Schmid and Axhausen, 2019). As the technology has significantly flourished in the past few years, the effect of social networking sites have had a more significant and substantial impact on one's life than before (Ahmed et al., 2019). In the field of marketing, e-business and social media has drastically changed the competition of markets by being more efficient and significant (Heath, 2019). According to Chi, "social media marketing is a relationship between brands and consumers, which offers a personal channel and currency for user-centered networking and social interaction" (2011). Marketing through social media keeps consumers in the focus of the corporate world and entrepreneurships. 
It provides them with creative and innovative segments, allowing marketers to grab the consumers' attention and maximize efficient purchasing behavior (Vasić et al., 2019). The most significant and exciting feature is its speed and efficiency, as a potential customer is just one click away (Hossain, 2019) and it is only a few further clicks until a product is purchased. Therefore, it is not possible to grab the market without knowing its technological importance, and businesses must focus on attractive packages, policies, promotions, and offers to enhance purchasing behavior for a sustainable economy (Wai et al., 2019). Since the approach for interacting with customers has changed because of social media, businesses should learn how effectively they can use social media to improve their sales (Mangold and Faulds, 2009). The practical and smart use of social media benefits companies (Alam et al., 2020) struggling to get a competitive edge (Liu et al., 2008; Sarfraz et al., 2020a,b; Li et al., 2021).

It is essential to acknowledge that social media works as a platform where companies and customers interact directly for mutual benefits (Tandon, 2020). Hence, it is equally important to observe and interpret their customers' behavior to achieve the maximum benefits (Cao et al., 2018). According to an estimation, over 500 million people are using social media (Facebook) (Ostrow et al., 2019)\{\#246\}. It is impossible to read and address such a large number of individuals without social media help and entrepreneurships (Cao et al., 2018). Consumer behavior is most important in marketing, as (Huo et al., 2020) it helps and guides the marketers to plan their strategies and tactics more efficiently (Hair and Sarstedt, 2021). The consumer-socialization theory predicts that communication among consumers affects their affective (Harrigan et al., 2021), cognitive, and behavioral attitudes (Ward, 1974). Hence, if one happy customer exists, they will bring more customers because of their positive experience with a specific brand and will surely recommend it to friends or family. This cycle keeps on moving (Harrigan et al., 2021). When a particular brand focuses on their customers happiness, it creates a positive brand reputation among customers' friends (Lipsman et al., 2012). Therefore, when a product is marketed through social media, it has multiple chances of spreading considerably because of the consumer-socialization theory (Meire et al., 2019; Sarfraz et al., 2020c). So, it is vital to check how effectively companies use social media to attract and influence their targeted consumers apart from just marketing their products.

It is also imperative to remember that every person following social media is not the actual customer of that specific company or brand. So, it is equally crucial for a company to convert those random followers into loyal and happy customers. According to Lipsman et al. a fan's value can be analyzed in three ways: increasing the depth of loyalty and engagement among fans, generating incremental purchase behaviur, and leveraging fans' ability to influence friends. The major goal is to create a strong and impactful social media brand impression (Sheth, 2021). And this brand impression can convert the popularity of a company into actual financial value for the company. However, the basic need is to identify the key factors affecting the existing consumers, which will automatically help attract potential consumers to convert them into actual consumers through active marketing skills (Moorman et al., 2019).

\section{OBJECTIVES AND SIGNIFICANCE OF THE STUDY}

The purpose of this study is (1) to comprehensively study the existing literature, which explains how companies and entrepreneurships through a digital economy use social media marketing tools and techniques (Vinerean et al., 2013). They use it to shape their e-business/marketing strategies in entrepreneurships to influence consumer behaviur regarding particular products (Moorman et al., 2019). (2) The chapter will introduce social media today and how it helps companies market their products to specific audiences worldwide. (3) The chapter will discuss different marketing techniques that are put into use through social media marketing and will explain how these techniques prove fruitful for companies and entrepreneurships and sustainable digital economy in terms of financial gains. Going a step further, the chapter will also discuss in detail the consumer behaviors and attitudes from the perspective of existing literature and will try to explain the factors which play a role in determining or changing the attitude of a consumer toward a product or a company he or she comes across on social media (Sarfraz, 2018; Dar et al., 2019, 2020).

Therefore, information from all relevant research streams will be incorporated in this chapter such that it paves the way for further research (Heinonen, 2011). The chapter will also serve as a foundation for primary research and help evaluate and understand the primary research results. Hence, the literature will be coupled with the results from real life to provide useful conclusions and recommendations about the subject under consideration and will try to answer the research questions in this context (Lopez and Castaño, 2019).

\section{THEORETICAL BACKGROUND}

There are two mediating variables and two independent variables, given in Figure 1. These variables can influence the online digital purchase intention positively or negatively, which is a dependent variable. Moreover, it can enhance online shopping by giving or offering smooth and safe transactions in industrial organizations.

Consumer socialization theory forecasts that communication between consumers disturbs their affective, cognitive, and behavioral attitudes (Ward, 1974). Through socialization, consumers acquire consumption-related skills and attitudes toward the marketplace. The widely applied socialization framework delineates consumer knowledge processes and how people execute their parts as patrons in society (e.g., Moschis and Churchill, 1978; Churchill and Moschis, 1979; De Gregorio and Sung, 2010) and in the marketplace.

For a successful marketing relation with different variables, it is crucial to understand the importance of those variables or factors that directly or indirectly influence purchasing behavior. We explored the strong relationship between innovative design and social media advertisement and the perceived risks and benefits of online purchase intentions. We concluded that all of these critical factors are important for every marketer with strong cooperation required for a successful relationship. First, 


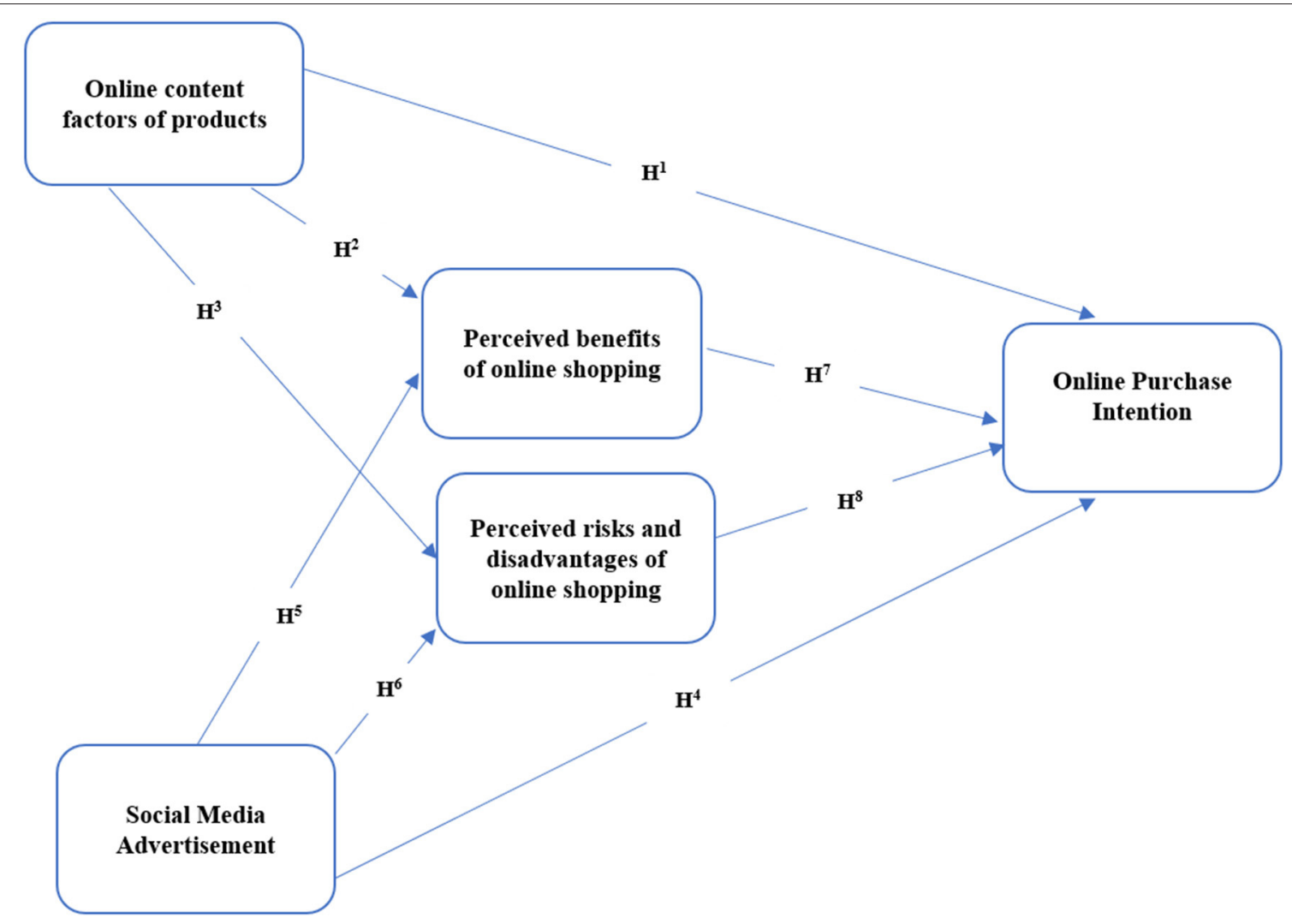

FIGURE 1 | Theoretical framework of the study.

we observe and study the nature of relationship marketing and recommend how this theory should be abstracted. Then, we conclude that successful relationship marketing needs strong social media advertisement and unique product design, and discuss the perceived benefits and factors that reduce the amount of risk. Next, we present them as a prominent and significant mediating variable. After that, we test those major mediating variables using data to build a strong marketing relationship online. Finally, we make a comparison with our rival to show whether our model allows the most substantial connection of these mediating variables. It is found that online competition is increasing on a daily basis among the markets (Thorelli, 1986, p. 47).

\section{LITERATURE REVIEW}

\section{Product Online Content Factors}

Product design includes style, aesthetics, function, and overall product outlook as the basic components or elements that could be created for a specific product (Schivinski et al., 2021). A company, entrepreneurship, or brand mostly focuses on these features and elements to distinguish it from others (Naeem, 2021). Core product elements are the heart of any product, such as the engine system of an automobile or a computer processor, and they should not be compromised at all (Sultan et al., 2021) as it would be noticed if these elements differed from one another. These functions also allow the customer to distinguish between you and your competitor. Hence, unique product design's responsibility can directly stimulate the customer's buying behavior (Amen et al., 2020). Therefore, the design is a collective process through which differences could be created easily (Huo et al., 2020).

An advanced package of different design essentials has made it exciting and easy to distinguish products in looks and functions to an exclusively reserved position in the market. Regrettably, most products fail to attain distinction in this way and to present their product more uniquely than others. Understanding its importance will ultimately lead to product success ( $\mathrm{Li}$ et al., 2020a). According to different research, the up-to-date view of the product began in the 1940's and 1950's. Other product designers were known as public figures and attained fame because of it (Loewy, 1950; Dreyfuss and Glimcher, 1955; Li et al., 2020b). Current designers must be efficient enough in all the essential or valuable fields, such as engineering, physical sciences, and social sciences (Molotch, 2005). A trio of impacts, from design, manufacturing, and marketing energies known as new product development and process of development. We started this study mainly to address the strategies, methods, goals, and tricks that product design teams can use to add value to customer attraction and satisfaction. 
H1: Online content factors create a positive online purchase intention in the consumer's mind.

H2: Online content factors create a positive online purchase intention in consumers' minds when mediated by the perceived benefits of online shopping.

H3: Online content factors create a positive online purchase intention in consumers' minds when mediated by perceived risks and disadvantages of online shopping.

\section{Social Media Advertisement}

This study aims to understand how brands and companies use social media advertisements to attract and influence consumer behaviurs toward their products (Voorveld et al., 2018). It is imperative to find and discuss how these attractions work to get maximum benefit (Alalwan, 2018). Understanding the foundations of social media marketing will help us evaluate how companies can use these tools to strengthen their brand image and thus (Alhabash et al., 2017) convert their followers into loyal buyers(Van-Tien Dao et al., 2014). It is also essential for a marketer to understand every social media feature before using it as a marketing or advertisement tool (Lee and Hong, 2016). According to Campbell et al. "social media is a lot more about how people are using the technology (Chu et al., 2013) and less about the technology itself. Because people are now creating and utilizing information instead of just storing it" (2011), social media can be defined as a tool or a complete package of different applications based on the technological base of web 2.0 which permits creating, innovating, or exchanging information through the internet (Chu et al., 2013). Furthermore, Web 2.0 could be explained more comprehensively as it is a totally new way where the information could be edited or created by the user anytime (Winter et al., 2021).

Purchase intention can be influenced because the contents of advertising and the message (Schivinski et al., 2021) through advertisement in social media are more eye catching and striking. Advertisements could be presented in numerous ways, like pictures, celebrity endorsement, or reviews of happy customers that could be uploaded (Naeem, 2021). The more powerful the message shared through visual advertisements, the more significant and positive a response could be collected from online consumers (Fotis et al., 2011). Wang et al. explains that the ads that appear very often leave a more significant impact on purchase intension. These ads do not have a specific message or maybe annoy the customer because of repetition (Sharma et al., 2021). Consumers may not resist a strong message or strong content that shares the product's innovating features and functions. The great increase in purchase intention will automatically lead to more sales (Hong and Kim, 2021).

H4: Social Media Advertisement creates a positive online purchase intention in the consumer's mind.

H5: Social Media Advertisement creates a positive online purchase intention in consumers' minds when mediated by the perceived benefits of online shopping.

H6: Social Media Advertisement creates a positive online purchase intention in consumers' minds when mediated by perceived risks and disadvantages of online shopping.

\section{Perceived Benefits of Online Shopping}

Online shopping predicts many risks, and there is always room for benefits and attractions that ultimately manipulate consumers' minds toward online shopping (Katta and Patro, 2017a). The perceived or the important benefits are related to consumer's satisfaction and happiness with online shopping and the perception of a consumer or customer is that online shopping is supposed to be easy, convenient, trustworthy, time saving, less risky (Tzeng et al., 2021), and offer more variety compared to conventional shopping. The internet has changed our life completely; as everything is just one click away, in seconds we could comfortably be looking at the best products or services. As per the findings of Seiders et al. (2000), convenience offers different prospects in the online buying method: Find, acquire, get, and complete the transaction. Furthermore (González et al., 2021), convenience is an essential and vital motivation for online shopping (González et al., 2021).

Additionally, convenience is significant and positively related to buying behaviur, which encourages a buyer's willingness (Wang et al., 2007). Moreover, Wang et al. (2021) websites provide a massive variety for a specific brand to multiple different consumers at a time using single platforms because there is no problem involved with storing or displaying the stock. An additional type is a motivational factor that stimulates consumers to purchase online (Katta and Patro, 2017b). It is very convenient for consumers to stay at home and acquire any product they want (Al-Debei et al., 2015).

It saves time. Any busy individual can purchase their products in just a few clicks (Hebbar et al., 2020). Online shopping provides different coupons, sale offers, deals, promotions, and much more. So, it is more attractive in terms of benefits over risks.

H7: Perceived benefits of online shopping creates a positive online purchase intention in the consumer's mind.

\section{Perceived Risk and Disadvantages of Online Shopping}

Perceived risk is well-defined by Dowling and Staelin (1994) as something that creates doubt in the consumer's mind to buy any specific goods or services. It has been demonstrated that perceived risk in consumer behavior is much more of an issue now than it has been in the past (Amirtha et al., 2021).

Product risk is the doubt a consumer has that the product will meet their expectations while making a purchase decision (Masri et al., 2021). Risk is experienced more in online shopping because the sense of physical experience and inspection is missing that cannot be passed on online (Tzeng et al., 2021). Traditional shopping provides better customer satisfaction as they can physically experience the product (Jain, 2021). That is why risk in traditional shopping is negligible as compared to advanced and speedy online shopping methods. It is the consumer's primary demand and concern (Lin et al., 2019). In shopping via technology, consumers have random or selective and very to-the-point information regarding a specific product. That is why they feel uncomfortable due to limited instructions (Lin et al., 2019). 
Privacy risk is the most significant issue related to online shopping (Islam, 2021). Consumers are supposed and compelled to share very private details to make any transaction possible (Peng et al., 2019). Moreover, as online shopping grows in popularity, so too does the risk associated with it, causing people to not want to buy online. Especially in Pakistan, a there was a decrease of online buyers from 3 to $2.07 \%$. Many people prefer cash on deliveries service because of that risk and do not want to share their bank details with the marketer or that website. According to Vasić et al. (2019), 8\% of online users stopped buying online due to privacy risks and more than $50 \%$ do not even want to try online shopping because they feel it is very risky and they are afraid of any problematic situation (Nazione et al., 2021). Privacy risks automatically lead toward people not buying online. Moreover, it does not meaningfully attract the consumer to make a purchase decision. Consumers' concern and insecurity about their personal information or a specific product result in negative effects on intentions (Qalati et al., 2021).

The intention of a consumer to shop online could be improved by ensuring that their private data is the brand's priority. A few findings show that "privacy risk significantly reduces online shopping behavior" (Yildirim et al., 2021). Therefore, the connection between risk and shopping online is powerful, and it is essential to discuss this to obtain maximum benegit. In the most recent findings, purchase intention could be used to strengthen the relationship between risk and purchase behavior (Zhong et al., 2021). Furthermore, different studies predict that there is no need to focus on privacy risk because people are neglecting its consequences in online shopping behavior (Lazaroiu et al., 2020).

H8: Perceived risks and disadvantages of online shopping create negative online purchase intention in consumers' minds.

\section{Online Purchase Intention}

Online purchase intention is the choice of an individual to purchase anything through the internet (Jain, 2021). While making a purchasing decision, the purpose could be affected by many factors that play vital roles like trust, time-saving, and convenience. If a lack of consumer purchase intention exists, it might cause significant problems because that specific person might influence others' behavior toward online shopping who are loyal or happy customers (Ma et al., 2021). Additionally, intentions are a collection of thoughts on whether an individual is willing to purchase or their specific buying behaviors (Jain, 2021).

Meanwhile, attractions through benefits and risks are the boosters of actual consumers' behavior. Most of the research describes a healthy and positive relationship among online shopping and purchase intentions (Chen et al., 2021; Ham and Chung, 2021) Many of the researchers found that it will help if our focus was on consumer purchase intention because it works well in online shopping to maintain a sustainable digital economy (Bhatti et al., 2018). There is an emerging trend to prioritize the latest trends in behaviur for the future because the future is all about online transactions (Chen and Zimitat, 2006; Bhatti et al., 2018).
TABLE 1 | Respondents' demographic profile.

\begin{tabular}{|c|c|c|c|}
\hline Category & Subdivision & Frequency & Percentage \\
\hline \multicolumn{4}{|c|}{ Demographic profile of the respondents } \\
\hline \multirow[t]{2}{*}{ Marital status } & Married & 150 & 60 \\
\hline & Un-married & 100 & 40 \\
\hline \multirow[t]{5}{*}{ Age } & Below 25 years & 50 & 2 \\
\hline & $25-30$ & 85 & 34 \\
\hline & $31-35$ & 65 & 26 \\
\hline & $36-40$ & 40 & 16 \\
\hline & 40 and above & 10 & 4 \\
\hline \multirow[t]{5}{*}{ Education } & Intermediate & 110 & 44 \\
\hline & Bachelors & 128 & 51 \\
\hline & Masters & 12 & 5 \\
\hline & M.Phil & 0 & 0 \\
\hline & Phd & 0 & 0 \\
\hline \multirow[t]{5}{*}{ Internet usage frequency } & Once in a day & 202 & 80.5 \\
\hline & After 3 days & 17 & 6.8 \\
\hline & After 1 week & 6 & 2.4 \\
\hline & After 2 weeks & 2 & 8 \\
\hline & After 1 month & 24 & 9.6 \\
\hline
\end{tabular}

\section{Research Methodology}

A hypothesis study has been used for this research to explain the nature of the relationship between a number of variables. Students from different educational institutes were drawn from the admission offices of their respective educational institutes. The reason for selecting students from universities is that they are heavy users of social media. They also have the highest probability of buying products online with the ability to spend money in hand.

This study used a correlational type of investigation because it needs to check the variables' relationship through hypotheses. Research has been conducted in a natural environment. That is why it will be considered a non-contrived study setting. This study has minimal researcher interference toward respondents regarding the filling out of questionnaires. In this study, the data is collected from students; that is why this study's unit of analysis is individual. The researcher has implemented a crosssectional study method for this study. It involves the study of a whole population, or a representative subset, at one specific point in time.

\section{Empirical Settings and Data Collection}

The data was obtained with respondent's consent. These studies have been conducted on students from different universities and educational institutes of the Punjab province; 500 questionnaires were distributed among them, and almost 270 questionnaires were returned, maintaining a response rate of $55 \%$. A reliable and valid questionnaire has been used for this study. As 20 questionnaires were returned with incomplete information, the analysis was done with 250 complete responses. Respondents' demographic profile is given in Table $\mathbf{1}$. 
The respondents were students from a variety of colleges and universities and were selected randomly using a simple random sampling technique. Respondents had to have experience using social media or online purchasing websites so that they could answer the questionnaire with more information and awareness.

\section{MEASURE AND METHODS}

\section{Instrument}

For measuring online content factors of products, perceived benefits of online shopping, and perceived risks and disadvantages of online shopping, we will use the scale developed by Adnan (2014). We will use the scale developed by Logan et al. (2012) and online purchase intention. We will use a scale developed by Duffett (2015). The instruments were rated and measured on a 5-point Likert scale with higher numerical values showing greater satisfaction.

\section{Confirmatory Factor Analysis}

It is necessary to conduct the confirmatory factor analysis for accurate and precise results for all variables. For this study, it was decided to conduct a pooled CFA analysis, which is given in Table 2. It runs all the latent variables at the same time to achieve the required model fitness. The pooled CFA method is a lot easier and better than the individual CFA since it runs all the latent variables simultaneously, which is time-saving (detail given in Table 3) (Afthanorhan et al., 2014; Chong et al., 2014).

The model fit indices show an acceptable fit between the data and the proposed measurement model. The values of the Comparative Fit Index $(\mathrm{CFI}=0.938)$, Root Mean Error of Approximation (RMSEA $=0.049$ ), and Chi-square to Degree of Freedom Ratio (x $2 / \mathrm{df}=1.590$ ) all meet the cutoff criteria, so the values of the fitness indices meet the excellent standards for model fitness (Lomax and Schumacker, 2004; Hoe, 2008; Anderson et al., 2010).

After running the pooled CFA, it is also necessary to check and verify each item's reliability for further research. CFA of this study's data was used to measure reliability, convergent validity, and discriminant validity. The reliability of the measurement scales was measured with composite reliability, which is preferred to report a scale's reliability (Netemeyer et al., 2003).

Discriminant validity is used to confirm that the measurement scales are distinct from other measures used in the study. Discriminant validity was measured using the HTMT analysis in which the cut-off criteria for strict discriminant validity is 0.850 and for liberal discriminant validity is 0.900 (details given in Table 4) (Henseler et al., 2015). Therefore, it is established that all the measurement scales used in the study differ from each other, so the data used in our study fulfils the requirements of convergent and discriminant validity and is suitable for further analysis.

\section{Structural Equation Modeling}

Structural equation modeling (SEM) was used in the structural model to test the hypotheses, using AMOS 24 (detail given in Table 5). As the proposed model contains mediation, the SEM technique was used to analyze all the paths simultaneously
(Iacobucci et al., 2007; Hoe, 2008; Alavifar et al., 2012). The model fit indices for the structural model meet the acceptance criteria.

\section{Hypothesis Testing}

The results of the structural model are shown in Table 6. The SEM statistics show that H1 (Content Factors $\rightarrow$ Purchase Intention) and $\mathbf{H 4}$ (Social Media Advertisement $\rightarrow$ Purchase Intention) are rejected on the grounds of significance level, as the SEM results show that the $P$-values of these hypotheses are not significant. These results suggest that these variables do not have a direct significant positive impact on employee loyalty. While H7 (Perceived benefits $\rightarrow$ Purchase Intention) and $\mathbf{H 8}$ (Perceived Risks $\rightarrow$ Purchase Intention) are accepted on the grounds of significance level, as the SEM results show that the $P$-values of these hypotheses are significant. These results suggest that these variables have a direct significant positive impact on employee loyalty. Moreover, the results also indicate that high perceived benefits could lead to positive purchase intention, directly proportional to independent and dependent variables. In contrast, the higher perceived risk could lead toward negative purchase intention and vice versa.

These results shown in Table 7 display the complete picture of this research study. The study showed that H2 (Content Factors $\rightarrow$ Perceived Benefits $\rightarrow$ Online Purchase Intention, $\boldsymbol{\beta}=\mathbf{0 . 2 0}, \boldsymbol{P}=\mathbf{0 . 0 0 5}$ ) is positively significant and suggests that when websites impressively use the product content factor then it is effective in enhancing the product's perceived benefits in the eyes of its target customer, hence leads toward positive online purchase intention behavior.

The study showed that H3 (Social Media Advertisement $\rightarrow$ Perceived Risks $\rightarrow$ Online Purchase Intention, $\beta=\mathbf{0 . 5 5}$, $\boldsymbol{P}=\mathbf{0 . 0 4 5 )}$ is also positively significant and suggests that organizations that use social media advertising to promote their products online create a positive impact in their targeted customer's online purchase intentions.

This hypothesis showed that H5 (Content Factors $\rightarrow$ Perceived Risks Online $\rightarrow$ Purchase Intention, $\boldsymbol{\beta}=\mathbf{0 . 3 5}, \boldsymbol{P}=\mathbf{0 . 0 2 6}$ ) is positively significant and suggests that content factors of the available online create a positive online purchase intention when perceived risks mediate it. Hence, it could be deducted that content factors help lower the perceived risks in buyers' minds and enhance their online purchase intention toward that specific product.

This specific hypothesis showed that H6 (Social Media Advertisement $\rightarrow$ Perceived Risks $\rightarrow$ Purchase Intention, $\beta=$ 0.25, $\boldsymbol{P}=\mathbf{0 . 0 0 9}$ ) is also positively significant and suggests that organizations' investment on social media advertisement is useful and creates a positive online purchase intention in its target customers.

\section{DISCUSSION}

This study's primary purpose was to encounter all the variables that may increase or decrease intention toward a valuable consumer's purchase behavior. There are multiple significant and positive relationships or dimensions that may influence an individual's shopping online. 
TABLE 2 | Pooled CFA model fitness tests.

\begin{tabular}{|c|c|c|c|c|c|}
\hline Name of category & Name of index & Index full name & Value in analysis & Acceptable value & References \\
\hline \multicolumn{6}{|c|}{ Pooled CFA model fitness tests } \\
\hline Absolute fit & RMSEA & $\begin{array}{l}\text { Root mean square of error } \\
\text { approximation }\end{array}$ & 0.049 & $<0.80$ & $\begin{array}{l}\text { Browne and } \\
\text { Cudeck, } 1993\end{array}$ \\
\hline Incremental fit & CFI & Comparative fit index & 0.938 & $>0.90$ & Bentler, 1990 \\
\hline Parsimonious fit & Chisq/df & $\begin{array}{l}\text { Chi Square/Degrees of } \\
\text { freedom }\end{array}$ & 1.590 & $<3$ & $\begin{array}{c}\text { Hu and Bentler, } \\
1999\end{array}$ \\
\hline
\end{tabular}

TABLE 3 | Pooled confirmatory factor analysis (Independent, mediating, and dependent variable).

\begin{tabular}{llcc}
\hline Scale Items & Factor loadings
\end{tabular}

Pooled confirmatory factor analysis (independent, mediating, and dependent variable)

Online content factors

of products

Social media advertisement

Perceived benefits of online shopping

Perceived risks and disadvantages of online shopping

Online Purchase Intention
I buy from online stores only if they are visually appealing and have a well-organized appearance.

I buy from online stores only if the navigation flow is user friendly.

I buy from online stores only if the site content is easy for me to understand and the information provided is relevant.

I buy from online stores only if they have an easy and error free ordering and transaction procedure.

Social media advertising is a good source of product information and supplies relevant product information.

Social media advertising provides timely information.

Social media advertising is a good source of up-to-date product information.

Social media advertising is a convenient source of product information. $\quad 0.856$

$\begin{array}{ll}\text { Social media advertising supplies complete product information. } & 0.708\end{array}$

I shop online as I can shop whenever I want to (24/7 availability). $\quad 0.707$

0.740

0.656

0.742

0.770

0.777

0.993

0.558

0.739

0.640

I shop online because I get a broader selection of products and better deals available.

Online shopping gives the facility of easy price comparison (Hence, price advantage).

I shop online as I get user/expert reviews on the product.

0.701

I use online shopping for buying products which are otherwise not easily available in the nearby market or are unique/new

I shop online as there are more payment options available.

I hesitate to shop online as there is a high risk of receiving malfunctioning merchandise.

It is hard to judge the quality of the merchandise over the internet.

I feel that there will be difficulty in settling disputes when I shop online (e.g., while exchanging products).

I might not receive the product ordered online.

0.703

I do not like being charged for shipping when I shop online.

Getting good after sale service is time taking and difficult for online purchases.

I will buy products that are advertised on social media.

0.709

I desire to buy products that are promoted on advertisements on social media.

I am likely to buy products that are promoted on social media.

0.776

0.656

0.742

0.802

0.816

0.605

0.775

0.825

0.825

0.763

0.543

I plan to purchase products that are promoted on social media.
0.705 
TABLE 4 | HTMT analysis to measure discriminant validity.

\section{Content factor}

\section{Social media}

advertisement

Perceived benefits

Perceived risks

Online purchase

intention

\section{HTMT analysis}

Content factor

Social media advertisement

Perceived benefits

Perceived risks

Online purchase intention

0.275
0.272
0.107
0.320

0.167
0.095
0.070

0.050
0.055

0.578

TABLE 5 | Structural equation modeling analysis.

\begin{tabular}{|c|c|c|c|c|c|}
\hline Name of category & Name of index & Index full name & Value in analysis & Acceptable value & References \\
\hline \multicolumn{6}{|c|}{ SEM, model fitness tests } \\
\hline Absolute fit & RMSEA & $\begin{array}{l}\text { Root mean square of } \\
\text { error approximation }\end{array}$ & 0.067 & $<0.80$ & $\begin{array}{l}\text { Browne and } \\
\text { Cudeck, } 1993\end{array}$ \\
\hline Incremental fit & CFI & Comparative fit index & 0.915 & $>0.90$ & Bentler, 1990 \\
\hline Parsimonious fit & Chisq/df & $\begin{array}{l}\text { Chi square/degrees of } \\
\text { freedom }\end{array}$ & 1.214 & $<3$ & $\begin{array}{c}\text { Hu and Bentler, } \\
1999\end{array}$ \\
\hline
\end{tabular}

TABLE 6 | Direct findings of the SEM.

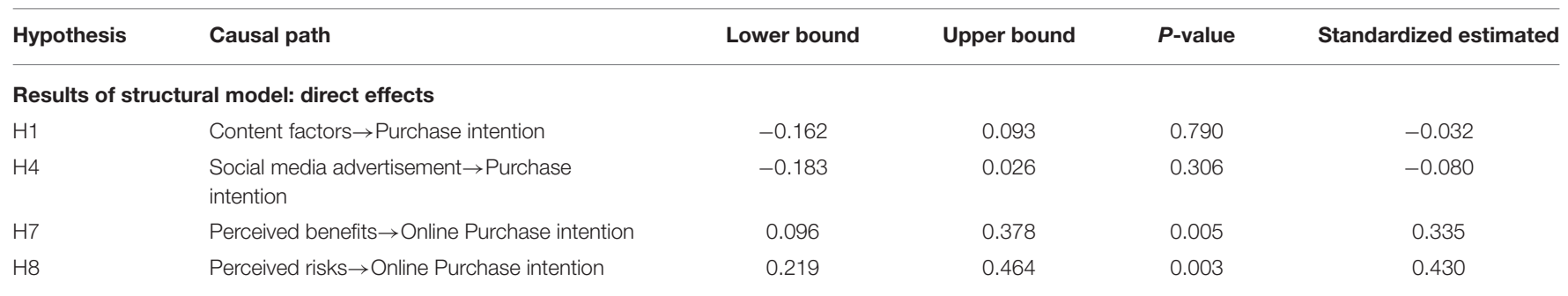

TABLE 7 | Indirect findings of the SEM.

\begin{tabular}{|c|c|c|c|c|c|}
\hline Hypothesis & Causal path & Lower bound & Upper bound & $\boldsymbol{P}$-value & Standardized estimated \\
\hline \multicolumn{6}{|c|}{ Results of structural model: indirect effects } \\
\hline $\mathrm{H} 2$ & $\begin{array}{l}\text { Content factors } \rightarrow \text { Perceived } \\
\text { Benefits } \rightarrow \text { Purchase intention }\end{array}$ & 0.060 & 0.174 & 0.005 & 0.20 \\
\hline H5 & $\begin{array}{l}\text { Social media advertisement } \rightarrow \text { Perceived } \\
\text { benefits } \rightarrow \text { Purchase intention }\end{array}$ & 0.027 & 0.140 & 0.045 & 0.55 \\
\hline H3 & $\begin{array}{l}\text { Content factors } \rightarrow \text { Perceived } \\
\text { Risks } \rightarrow \text { Purchase Intention }\end{array}$ & 0.052 & 0.153 & 0.026 & 0.35 \\
\hline $\mathrm{H} 6$ & $\begin{array}{l}\text { Social media advertisement } \rightarrow \text { Perceived } \\
\text { risks } \rightarrow \text { Purchase intention }\end{array}$ & 0.019 & 0.098 & 0.009 & 0.25 \\
\hline
\end{tabular}

Innovative and creative design, ads through social media, and benefits and risks related to online purchase intentions directly affect consumers' buying behavior. So, the marketers have a significant gap to capture the market entirely and create a competitive edge.

In this research, we found that married people between 25 and 30 are more inclined to shop online. So, existing marketers can mold their advertisements according to this age group's interest, and they will automatically influence their social circle and community.

More benefits like giving a cash on delivery option or providing them with a trial option makes consumers feel the experience is more convenient and are happier about that product. It will create a significant difference among marketers.

On the other hand, the risk could be controlled more efficiently by providing the customer with ease and choices. The shared findings show that the relationship between benefits and 
risks is not only important in marketing relationship, but also that there are many more factors which are equally important and demand investigation in entrepreneurship (Becker, 1960; Achrol, 1991; Dwyer et al., 2001). They are also key mediating variables in these relationships. We found that the relationship among these variables is significantly and positively related with the desired outcomes.

Moreover, more variables could be added to get different opinions on where to work and how to work, especially for online shopping. A specific gender could be chosen to get other markets, but the variables discussed in this research give a clear direction for the existing and new markets.

\section{CONCLUSION}

This study showed that both techniques are helpful in enhancing the online purchase intention of target customers while mediated by a product's perceived risks and benefits. But for specific actions, social media advertisement is more useful in enhancing the perceived benefits of those products available for sale online (Michaelidou et al., 2011; Kim and Ko, 2012). At the same time, the content factors or product listing is more helpful in lowering the perceived risks associated with any available product online. These conclusions are also backed up by other studies conducted (Hong et al., 2004; Schmutz et al., 2010; Boateng and Okoe, 2015). Moreover, the impact of control variables still needed to be discussed in this research work. The specific variables which are selected for this research could perform indifferently in different situations. The results of this study could help organizations promote their product and services so that they could minimize their promotional costing of that product, lower the perceived risks associated with their product, and elevate the perceived benefits effectively.

\section{REFERENCES}

Achrol, R. S. (1991). Evolution of the marketing organization: new forms for turbulent environments. J. Market. 55, 77-93. doi: $10.1177 / 002224299105500406$

Adnan, H. (2014). An analysis of the factors affecting online purchasing behavior of Pakistani consumers. Int. J. Mark. Stud. 6:133. doi: 10.5539/ijms.v6n5p133

Afthanorhan, W., Ahmad, S., and Mamat, I. (2014). Pooled confirmatory factor analysis (PCFA) using structural equation modeling on volunteerism program: a step by step approach. Int. J. Asian Soc. Sci. 4, 642-653.

Ahmed, B. S., Amroush, F., and Maati, M. B. (2019). "The intelligence of E-CRM applications and approaches on online shopping industry," in Advanced Methodologies and Technologies in Digital Marketing and Entrepreneurship, eds D. B. A. Mehdi Khosrow-Pour (IGI Global), 70-82. doi: 10.4018/978-1-5225-7766-9.ch006

Alalwan, A. A. (2018). Investigating the impact of social media advertising features on customer purchase intention. Int. J. Inf. Manage 42, 65-77. doi: 10.1016/j.ijinfomgt.2018.06.001

Alam, G. M., Parvin, M., Ayub, A. F. B. M., Kader, R., and Rahman, M. M. (2020). Does an MBA degree advance business management skill or in fact create horizontal and vertical mismatches? Bus. Process Manag. J. doi: 10.1108/BPMJ-10-2020-0465. [Epub ahead of print].

Alavifar, A., Karimimalayer, M., and Anuar, M. K. (2012). Structural equation modeling vs multiple regression. Eng. Sci. Technol. 2, 326-329.
Finally, this study's results could also vary from time to time due to demographics and geographic changes. That is why it is strongly recommended to apply this research framework in other situations or even the same problem again to verify and generalize the said results.

Despite these collaborative and managerial implications, this study has numerous limitations that provide salient future research directions. First, the websites included were not categorized according to region, so the respondent data was not associated with norms and cultural background. So, there is much more work required regarding this aspect. In addition, there are different marketing techniques to enhance purchase intention.

\section{DATA AVAILABILITY STATEMENT}

The original contributions presented in the study are included in the article/supplementary material, further inquiries can be directed to the Corresponding author/s.

\section{AUTHOR CONTRIBUTIONS}

DD: writing main draft and analysis. HA: revised the draft, data collection, and improved the article. YL: lead this study, final draft, and analysis. EE: layout, framework, and analysis elucidation. AM and JK: data, proof read, and language editing. All authors contributed to the article and approved the submitted version.

\section{FUNDING}

The authors extend their appreciation to the Deanship of Scientific Research at King Saud University, Saudi Arabia for funding this work research group number RG-1439-015.

Al-Debei, M. M., Akroush, M. N., and Ashouri, M. I. (2015). Consumer attitudes toward online shopping: the effects of trust, perceived benefits, and perceived web quality. Internet Res. 25, 707-733. doi: 10.1108/IntR-05-2014-0146

Alhabash, S., Mundel, J., and Hussain, S. A. (2017). Social media advertising. Digit. Adv. 285:15. doi: 10.4324/9781315623252-16

Amen, R., Hameed, J., Albashar, G., Kamran, H. W., Shah, M. U. H., Zaman, K. U., et al. (2020). Modeling the higher heating value of municipal solid waste for assessment of waste-to-energy potential: a sustainable case study. J. Clean. Prod. 287:125575. doi: 10.1016/j.jclepro.2020.125575

Amirtha, R., Sivakumar, V., and Hwang, Y. (2021). Influence of perceived risk dimensions on e-shopping behavioural intention among women-a family life cycle stage perspective. J. Theor. Appl. Electr. Commer. Res. 16, 320-355. doi: 10.3390/jtaer16030022

Anderson, R., Babin, B., Black, W., and Hair, J. (2010). Multivariate Data Analysis: A Global Perspective. Upper Saddle River: Pearson prentice Hall.

Becker, H. S. (1960). Notes on the concept of commitment. Am. J. Sociol. 66, 32-40. doi: $10.1086 / 222820$

Bentler, P. M. (1990). Comparative fit indexes in structural models. Psychol. Bull. 107:238. doi: 10.1037/0033-2909.107.2.238

Bhatti, A., Saad, S., and Gbadebo, S. M. (2018). Convenience risk, product risk, and perceived risk influence on online shopping: moderating effect of attitude. Sci. Arena Publ. Int. J. Bus. Manage. 3, 1-11.

Boateng, H., and Okoe, A. F. (2015). Consumers' attitude toward social media advertising and their behavioural response. J. Res. Interactive Mark. 9, 299-312. doi: 10.1108/JRIM-01-2015-0012 
Browne, M. W., and Cudeck, R. (1993). Alternative ways of assessing model fit. Sage Focus Ed. 154:136.

Cao, Y., Ajjan, H., and Hong, P. (2018). Post-purchase shipping and customer service experiences in online shopping and their impact on customer satisfaction. Asia Pac. J. Mark. Logistics 30, 400-416. doi: 10.1108/APJML-04-2017-0071

Chen, C.-J., Tsai, P.-H., and Tang, J.-W. (2021). How informational-based readiness and social influence affect usage intentions of self-service stores through different routes: an elaboration likelihood model perspective. Asia Pac. Bus. Rev. 1-30. doi: 10.1080/13602381.2021.187 2912

Chen, C. H., and Zimitat, C. (2006). Understanding Taiwanese students' decisionmaking factors regarding Australian international higher education. Int. J. Educ. Manage. 20, 91-100. doi: 10.1108/09513540610646082

Chong, E. E., Nazim, A., and Ahmad, S. B. (2014). A comparison between individual confirmatory factor analysis and pooled confirmatory factor analysis: an analysis of library service quality, a case study at a public university in Terengganu. Int. J. Eng. Sci. Innovative Technol. 3, 110-116.

Chu, S.-C., Kamal, S., and Kim, Y. (2013). Understanding consumers' responses toward social media advertising and purchase intention toward luxury products. J. Glob. Fashion Mark. 4, 158-174. doi: 10.1080/20932685.2013.790709

Churchill Jr, G. A., and Moschis, G. P. (1979). Television and interpersonal influences on adolescent consumer learning. J. Cons. Res. 6, 23-35. doi: $10.1086 / 208745$

Dar, A. A., Chen, J., Shad, A., Pan, X., Yao, J., Bin-Jumah, M., et al. (2020). A combined experimental and computational study on the oxidative degradation of bromophenols by Fe (VI) and the formation of self-coupling products. Environ. Pollut. 258:113678. doi: 10.1016/j.envpol.2019.113678

Dar, A. A., Wang, X., Wang, S., Ge, J., Shad, A., Ai, F., et al. (2019). Ozonation of pentabromophenol in aqueous basic medium: kinetics, pathways, mechanism, dimerisation and toxicity assessment. Chemosphere 220, 546-555. doi: 10.1016/j.chemosphere.2018.12.154

De Gregorio, F., and Sung, Y. (2010). Understanding attitudes toward and behaviors in response to product placement. J. Advert. 39, 83-96. doi: 10.2753/JOA0091-3367390106

Dowling, G. R., and Staelin, R. (1994). A model of perceived risk and intended risk-handling activity. J. Consum. Res. 21, 119-134.

Dreyfuss, J. R., and Glimcher, M. J. (1955). Epiphyseal injury following frostbite. New Engl. J. Med. 253, 1065-1068. doi: 10.1056/NEJM195512152532404

Duffett, R. G. (2015). Facebook advertising's influence on intention-topurchase and purchase amongst millennials. Internet Res. 25, 498-526. doi: 10.1108/IntR-01-2014-0020

Dwyer, F. R., Schurr, P. H., and Oh, S. (2001). "Developing buyer-seller relationships," in Marketing: Critical Perspectives on Business and Management, 194-225. doi: 10.2307/1251126

Fotis, J., Buhalis, D., and Rossides, N. (2011). Social media impact on holiday travel planning: the case of the Russian and the FSU markets. Int. J. Online Mark. 1, 1-19. doi: 10.4018/ijom.2011100101

González, E. M., Meyer, J.-H., and Toldos, M. P. (2021). What women want? How contextual product displays influence women's online shopping behavior. J. Bus. Res. 123, 625-641. doi: 10.1016/j.jbusres.2020.10.002

Hair, J. F. Jr., and Sarstedt, M. (2021). Data, measurement, and causal inferences in machine learning: opportunities and challenges for marketing. J. Mark. Theory Pract. 29, 65-77. doi: 10.1080/10696679.2020.1860683

Ham, J., and Chung, N. (2021). "The role of perceived technology and consumers' personality traits for trust transfer in airbnb," in Information and Communication Technologies in Tourism 2021, eds W. Wörndl, C. Koo, and J. L. Stienmetz (Cham: Springer), 128-133. doi: 10.1007/978-3-030-65785-7_11

Harrigan, P., Daly, T. M., Coussement, K., Lee, J. A., Soutar, G. N., and Evers, U. (2021). Identifying influencers on social media. Int. J. Inf. Manage. 56:102246. doi: 10.1016/j.ijinfomgt.2020.102246

Heath, S. (2019). System and Method for Social Networking Interactions Using Online Consumer Browsing Behavior, Buying Patterns, Advertisements and Affiliate Advertising, for Promotions, Online Coupons, Mobile Services, Products, Goods and Services, Entertainment and Auctions, With Geospatial Mapping Technology. US20130073473A1. Washington, DC: U.S. Patent and Trademark Office.
Hebbar, S., Kamath, G. B., Mathew, A. O., and Kamath, V. (2020). Attitude toward online shopping and its influence on purchase intentions: an urban Indian perspective. Int. J. Bus. Innov. Res. 22, 326-341. doi: 10.1504/IJBIR.2020.107961

Heinonen, K. (2011). Consumer activity in social media: managerial approaches to consumers' social media behavior. J. Consum. Behav. 10, 356-364. doi: $10.1002 / \mathrm{cb} .376$

Henseler, J., Ringle, C. M., and Sarstedt, M. (2015). A new criterion for assessing discriminant validity in variance-based structural equation modeling. J. Acad. Mark. Sci. 43, 115-135. doi: 10.1007/s11747-014-0403-8

Hoe, S. L. (2008). Issues and procedures in adopting structural equation modeling technique. J. Appl. Quant. Methods 3, 76-83.

Hong, H., and Kim, Y. (2021). What makes people engage in civic activism on social media? Online Inf. Rev. doi: 10.1108/OIR-03-2020-0105

Hong, W., Thong, J. Y., and Tam, K. Y. (2004). Designing product listing pages on e-commerce websites: an examination of presentation mode and information format. Int. J. Hum. Comput. Stud. 61, 481-503. doi: 10.1016/j.ijhcs.2004.01.006

Hossain, S. F. A. (2019). Social networking and its role in media entrepreneurship: evaluating the use of mobile phones in the context of online shopping-a review. J. Media Manage. Entrep. 1, 73-86. doi: 10.4018/JMME.2019010105

Hu, L. T., and Bentler, P. M. (1999). Cutoff criteria for fit indexes in covariance structure analysis: conventional criteria versus new alternatives. Struct. Eq. Model. 6, 1-55. doi: 10.1080/10705519909540118

Huo, C., Dar, A. A., Nawaz, A., Hameed, J., Pan, B., and Wang, C. (2020). Groundwater contamination with the threat of COVID-19: insights into CSR theory of Carroll's pyramid. J. King Saud Univ. Sci. 33:101295. doi: 10.1016/j.jksus.2020.101295

Iacobucci, D., Saldanha, N., and Deng, X. (2007). A meditation on mediation: evidence that structural equations models perform better than regressions. $J$. Consum. Psychol. 17, 139-153. doi: 10.1016/S1057-7408(07)70020-7

Islam, M. S. (2021). Online shopping behaviour among international students from belt and road countries in China. Eur. J. Bus. Manage. Res. 6, 63-75. doi: 10.24018/ejbmr.2021.6.1.681

Jain, S. (2021). Examining the moderating role of perceived risk and web atmospherics in online luxury purchase intention. J. Fashion Mark. Manage. doi: 10.1108/JFMM-05-2020-0089

Katta, R. M. R., and Patro, C. S. (2017a). Influence of perceived benefits on consumers' online purchase behaviour: an empirical study. Int. J. Sociotechnol. Knowled. Dev. 9, 38-64. doi: 10.4018/IJSKD.2017070103

Katta, R. M. R., and Patro, C. S. (2017b). Influence of perceived risks on consumers' online purchase behaviour: a study. Int. J. Sociotechnol. Knowled. Dev. 9, 17-37. doi: 10.4018/IJSKD.2017070102

Kim, A. J., and Ko, E. (2012). Do social media marketing activities enhance customer equity? An empirical study of luxury fashion brand. J. Bus. Res. 65, 1480-1486. doi: 10.1016/j.jbusres.2011.10.014

Lazaroiu, G., Negurita, O., Grecu, I., Grecu, G., and Mitran, P. C. (2020). Consumers' decision-making process on social commerce platforms: online trust, perceived risk, and purchase intentions. Front. Psychol. 11:890. doi: 10.3389/fpsyg.2020.00890

Lee, J., and Hong, I. B. (2016). Predicting positive user responses to social media advertising: the roles of emotional appeal, informativeness, and creativity. Int. J. Inf. Manage. 36, 360-373. doi: 10.1016/j.ijinfomgt.2016.01.001

Li, H., Hameed, J., Khuhro, R. A., Albasher, G., Alqahtani, W., Sadiq, M. W., et al. (2021). The impact of the economic corridor on economic stability: a double mediating role of environmental sustainability and sustainable development under the exceptional circumstances of COVID-19. Front. Psychol. 11:634375. doi: 10.3389 /fpsyg. 2020.634375

Li, H., Inzamam, U. H., Hira, N., Gadah, A., Wedad, A., Ahsan, N., et al. (2020a). How environmental awareness relates to green purchase intentions can affect brand evangelism? altruism and environmental consciousness as mediators. Int. J. Early Childhood Special Educ. 811-825. [Epub ahead of print].

Li, H., Javaria, H., Rafiq, K., Gadah, A., Wedad, A., Muhammad, W., et al. (2020b). The impact of economic corridor on the economic stability: a double mediating role of environmental sustainability and sustainable development under the exceptional circumstances of COVID-19. Front. Psychol. 11:4025.

Lin, X., Featherman, M., Brooks, S. L., and Hajli, N. (2019). Exploring gender differences in online consumer purchase decision making: an online product presentation perspective. Inf. Syst. Front. 21, 1187-1201. doi: $10.1007 /$ s10796-018-9831-1 
Lipsman, A., Mudd, G., Rich, M., and Bruich, S. (2012). The power of "like": How brands reach (and influence) fans through social-media marketing. J. Advert. Res. 52, 40-52. doi: 10.2501/JAR-52-1-040-052

Liu, X., He, M., Gao, F., and Xie, P. (2008). An empirical study of online shopping customer satisfaction in China: a holistic perspective. Int. J. Retail Distrib. Manage. 36, 919-940. doi: 10.1108/09590550810911683

Loewy, F. E. (1950). Morphine in asthma. Br. Med. J. 1:1143.

Logan, K., Bright, L. F., and Gangadharbatla, H. (2012). Facebook versus television: advertising value perceptions among females. J. Res. Interact. Mark. 6, 164-179. doi: $10.1108 / 17505931211274651$

Lomax, R. G., and Schumacker, R. E. (2004). A Beginner's Guide to Structural Equation Modeling. New york, NY: Psychology press. doi: $10.4324 / 9781410610904$

Lopez, A., and Castaño, R. (2019). Consumer behavior on social media: a thematic exploration and an agenda for future inquiry. Bus. Govern. Soc. 281-301. doi: 10.1007/978-3-319-94613-9_17

Ma, L., Zhang, X., Ding, X., and Wang, G. (2021). How social ties influence customers' involvement and online purchase intentions. J. Theor. Appl. Electron. Commer. Res. 16, 395-408. doi: 10.3390/jtaer16030025

Mangold, W. G., and Faulds, D. J. (2009). Social media: the new hybrid element of the promotion mix. Bus. Horizons 52, 357-365. doi: 10.1016/j.bushor.2009.03.002

Masri, N. W., Ruangkanjanases, A., and Chen, S.-C. (2021). The effects of product monetary value, product evaluation cost, and customer enjoyment on customer intention to purchase and reuse vendors: institutional trust-based mechanisms. Sustainability 13:172. doi: 10.3390/su13010172

Meire, M., Hewett, K., Ballings, M., Kumar, V., and Van den Poel, D. (2019). The role of marketer-generated content in customer engagement marketing. J. Mark. 83, 21-42. doi: 10.1177/0022242919873903

Michaelidou, N., Siamagka, N. T., and Christodoulides, G. (2011). Usage, barriers and measurement of social media marketing: An exploratory investigation of small and medium B2B brands. Ind. Market. Manag. 40, 1153-1159. doi: 10.1016/j.indmarman.2011.09.009

Molotch, H. (2005). Extravaganzas of show and tell: industrial designers Society of America Annual Convention Pasadena, CA, October 27-30, 2004. Contexts 4, 74-75. doi: $10.1525 / \mathrm{ctx} .2005 .4 .2 .74$

Moorman, C., van Heerde, H. J., Moreau, C. P., and Palmatier, R. W. (2019). Challenging the Boundaries of Marketin. Los Angeles, CA: SAGE Publications Sage CA. doi: 10.1177/0022242919867086

Moschis, G. P., and Churchill Jr, G. A. (1978). Consumer socialization: a theoretical and empirical analysis. J. Market. Res. 15, 599-609.

Naeem, M. (2021). Do social media platforms develop consumer panic buying during the fear of Covid-19 pandemic. J. Retailing Consum. Serv. 58:102226. doi: 10.1016/j.jretconser.2020.102226

Nazione, S., Perrault, E., and Pace, K. (2021). Impact of information exposure on perceived risk, efficacy, and preventative behaviors at the beginning of the COVID-19 pandemic in the United States. Health Commun. 36, 23-31. doi: 10.1080/10410236.2020.1847446

Netemeyer, R. G., Bearden, W. O., and Sharma, S. (2003). Scaling Procedures: Issues and Applications. Thousand Oaks, CA: Sage Publications. doi: $10.4135 / 9781412985772$

Ostrow, L., Croft, B., Weaver, A., and Naeger, S. (2019). An exploratory analysis of the role of social supports in psychiatric medication discontinuation: results related to family involvement. Psychosis 11, 212-222. doi: 10.1080/17522439.2019.1615110

Peng, L., Zhang, W., Wang, X., and Liang, S. (2019). Moderating effects of time pressure on the relationship between perceived value and purchase intention in social E-commerce sales promotion: considering the impact of product involvement. Inf. Manage. 56, 317-328. doi: 10.1016/j.im.2018.11.007

Qalati, S. A., Vela, E. G., Li, W., Dakhan, S. A., Hong Thuy, T. T., and Merani, S. H. (2021). Effects of perceived service quality, website quality, and reputation on purchase intention: the mediating and moderating roles of trust and perceived risk in online shopping. Cogent Bus. Manage. 8:1869363. doi: $10.1080 / 23311975.2020 .1869363$

Sarfraz, M. (2018). A moment-based quasilinear theory for electron firehose instability driven by solar wind core/halo electrons. J. Geophys. Res. 123, 6107-6118. doi: 10.1029/2018JA025449
Sarfraz, M., He, B., and Shah, S. G. M. (2020c). Elucidating the effectiveness of cognitive $\mathrm{CEO}$ on corporate environmental performance: The mediating role of corporate innovation. Environ. Sci. Pollut. Res. 27, 45938-45948. doi: $10.1007 / \mathrm{s} 11356-020-10496-7$

Sarfraz, M., Ozturk, I., Shah, S. G. M., and Maqbool, A. (2020b). Contemplating the impact of the moderators agency cost and number of supervisors on corporate sustainability under the aegis of a cognitive CEO. Front. Psychol. 11:965. doi: 10.3389/fpsyg.2020.00965

Sarfraz, M., Shah, S. G., Fareed, Z., and Shahzad, F. (2020a). Demonstrating the interconnection of hierarchical order disturbances in CEO succession with corporate social responsibility and environmental sustainability. Corp. Soc. Respons. Environ. Manag. 27, 2956-2971. doi: 10.1002/csr.2014

Schivinski, B., Muntinga, D. G., Pontes, H. M., and Lukasik, P. (2021). Influencing COBRAs: the effects of brand equity on the consumer's propensity to engage with brand-related content on social media. J. Strateg. Mark. 29, 1-23. doi: 10.1080/0965254X.2019.1572641

Schmid, B., and Axhausen, K. W. (2019). In-store or online shopping of search and experience goods: a hybrid choice approach. J. Choice Model. 31, 156-180. doi: 10.1016/j.jocm.2018.03.001

Schmutz, P., Roth, S. P., Seckler, M., and Opwis, K. (2010). Designing product listing pages-effects on sales and users' cognitive workload. Int. J. Hum. Comput. Stud. 68, 423-431. doi: 10.1016/j.ijhcs.2010.02.001

Seiders, K., Berry, L. L., and Gresham, L. G. (2000). Attention, retailers! How convenient is your convenience strategy? MIT Sloan Manag. Rev. 41:79.

Sharma, S., Singh, S., Kujur, F., and Das, G. (2021). Social media activities and its influence on customer-brand relationship: an empirical study of apparel retailers' activity in India. J. Theor. Appl. Electron. Commer. Res. 16, 602-617. doi: $10.3390 /$ jtaer 16040036

Sheth, J. (2021). New areas of research in marketing strategy, consumer behavior, and marketing analytics: the future is bright. J. Mark. Theory Pract. 29, 3-12. doi: 10.1080/10696679.2020.1860679

Sultan, M. T., Sharmin, F., Badulescu, A., Stiubea, E., and Xue, K. (2021). Travelers' responsible environmental behavior toward sustainable coastal tourism: an empirical investigation on social media user-generated content. Sustainability 13:56. doi: $10.3390 /$ sul3010056

Tandon, U. (2020). Predictors of online shopping in India: an empirical investigation. J. Mark. Analyt. 9, 1-15. doi: 10.1057/s41270-020-00 084-6

Thorelli, H. B. (1986). Networks: between markets and hierarchies. Strat. Manag. J. 7, 37-51. doi: 10.1002/smj.4250070105

Tzeng, S.-Y., Ertz, M., Jo, M.-S., and Sarigöllü, E. (2021). Factors affecting customer satisfaction on online shopping holiday. Mark. Intell. Plan. doi: 10.1108/MIP-08-2020-0346

Van-Tien Dao, W., Nhat Hanh Le, A., Ming-Sung Cheng, J., and Chao Chen, D. (2014). Social media advertising value: the case of transitional economies in Southeast Asia. Int. J. Adv. 33, 271-294. doi: 10.2501/IJA-33-2-271-294

Vasić, N., Kilibarda, M., and Kaurin, T. (2019). The influence of online shopping determinants on customer satisfaction in the Serbian market. J. Theor. Appl. Electron. Commer. Res. 14, 70-89. doi: 10.4067/S0718-18762019000 200107

Vinerean, S., Cetina, I., Dumitrescu, L., and Tichindelean, M. (2013). The effects of social media marketing on online consumer behavior. Int. J. Bus. Manage. 8:66. doi: 10.5539/ijbm.v8n14p66

Voorveld, H. A., Van Noort, G., Muntinga, D. G., and Bronner, F. (2018). Engagement with social media and social media advertising: the differentiating role of platform type. J. Advert. 47, 38-54. doi: 10.1080/00913367.2017.1405754

Wai, K., Dastane, O., Johari, Z., and Ismail, N. B. (2019). Perceived risk factors affecting consumers' online shopping behaviour. J. Asian Finan. Econ. Bus. 6, 246-260. doi: 10.13106/jafeb.2019.vol6.no4.249

Wang, C., Walker, E., and Redmond, J. (2007). Explaining the lack of strategic planning in SMEs: the importance of owner motivation. Int. J. Org. Behav. 12, $1-16$.

Wang, F., Yuan, Y., and Lu, L. (2021). Dynamical prediction model of consumers' purchase intentions regarding anti-smog products during smog risk: taking the information flow perspective. Physica A 563:125427. doi: 10.1016/j.physa.2020.125427

Ward, S. (1974). Consumer Socialization. J. Cons. Res. 1, 1-14. doi: 10.1086/208584 
Winter, S., Maslowska, E., and Vos, A. L. (2021). The effects of trait-based personalisation in social media advertising. Comput. Hum. Behav. 114:106525. doi: $10.1016 /$ j.chb.2020.106525

Yildirim, M., Özaslan, A., and Arslan, G. (2021). Perceived risk and parental coronavirus anxiety in healthcare workers: a moderated mediation role of coronavirus fear and mental well-being. Psychol. Health Med. 1-12. doi: 10.1080/13548506.2021.1871771

Zhong, B., Huang, Y., and Liu, Q. (2021). Mental health toll from the coronavirus: social media usage reveals Wuhan residents' depression and secondary trauma in the COVID-19 outbreak. Comput. Hum. Behav. 114:106524. doi: $10.1016 /$ j.chb.2020.106524
Conflict of Interest: The authors declare that the research was conducted in the absence of any commercial or financial relationships that could be construed as a potential conflict of interest.

Copyright (๑ 2021 Dong, Malik, Liu, Elashkar, Shoukry and Khader. This is an open-access article distributed under the terms of the Creative Commons Attribution License (CC BY). The use, distribution or reproduction in other forums is permitted, provided the original author(s) and the copyright owner(s) are credited and that the original publication in this journal is cited, in accordance with accepted academic practice. No use, distribution or reproduction is permitted which does not comply with these terms. 